\author{
Д.Г. Трунов
}

\title{
ПРЕДСТАВЛЕНИЯ О СНОВИДЕНИЯХ: \\ РЕЛИГИОЗНАЯ, ЕСТЕСТВЕННОНАУЧНАЯ И ПСИХОЛОГИЧЕСКАЯ МОДЕЛИ
}

\begin{abstract}
Аннотация. В данной статье представлены основные исторические модели представлений о сновидениях: метафизическая, естественнонаучная и психологическая модели. Метафизическая модель предполагает, что источником сновидения является некий иной мир, а сновидение есть послание этого мира сновидиу. Естественнонаучная модель сновидений предусматривает, что сновидение является специфическим продуктом спонтанной деятельности спящего мозга, а потому не несёт какого-либо жизненно важного смысла сновидящему. Психологическая модель чаще всего рассматривает источником сновидения некую сферу психики, например, "бессознательное», а сновидение выполняет некие важные психологические функции. Сравнение моделей осуществляется по следующим критериям: источник сновидения, функция сновидения, причина сновидения, механизм сновидения, онейропрактики ("сновидческие практики»). Выявление трёх основных моделей представлений о сновидениях и их критериев позволяет изучать то, как интегрируются данные модели в индивидуальном сознании. Представления о сновидениях, которые имеет каждый отдельный человек, складываются из фрагментов различных моделей, в зависимости от содержания сновидения, своего мировоззрения и других факторов, сновидящий опирается в своём понимании сновидения на свою личную интегративную модель.
\end{abstract}

Ключевые слова: сновидения, представления о сновидениях, теория сновидений, толкование сновидений, онейропрактика, онейркритика, метафизическая модель, естественнонаучная модель, психологическая модель, онейротерапия.

Abstract. In this article Trunov describes the main historical models of the dreams concepts including metaphysical, natural-science and psychological models. According to the metaphysical model, the source of dreams is the other world and dreams are messages to a dreamer from that other world. Based on the natural-science model, dreams are a specific product of spontaneous activity produced by a sleeping mind and thus do not have any important meaning for a dreamer. Depending on the psychological model, the source of dreams is the mental sphere, namely, 'the unconscious', and dreams perform important psychological functions. The author of the article compares the aforesaid models based on the following criteria: the source of dreams, functions of dreams, reason of dreams, mechanism of dreaming and oneiropractices (dream interpretation practices). Description of the three main models and their criteria allows to analyze how these models are integrated in the individual consciousness. Our individual idea of what a dream is is based on the fragments of different models depending on the contents of a dream, our world view and other factors which allows us to create our own personal integrated model of dreams.

Key words: oneirotherapy, psychological model, natural-science model, metaphysical model, oneirocriticism, oneuropractice, oneirology, dream interpretation, theory of dreams, concepts of dreams, dreams.

$\mathrm{H}$ а всём протяжении своей истории люди не переставали размышлять о природе сновидений. Пытаясь объяснить эту часть своей жизни, они формулировали различные «теории сновидений», которые исходили из существующей картины мира и соответствующего взгляда на человека. Менялось мировоззрение, менялись и представления о сновидениях. И вот, на сегодняшний день мы имеем разнообразные «теории сновидений», созданные в рамках различных мировоззрений.

В данной статье будут представлены основные исторические модели представлений о сновидениях, сравнение которых будет основано на ряде критериев: источник сновидения: откуда появляются образы и персонажи сновидения; функция сновиде- 
ния: каково назначение сновидения; причина сновидения: что является инициирующим фактором сновидения; механизм сновидения: как формируется сновидение; онейропрактики («сновидческие практики»): что можно делать со сновидениями и как можно на них влиять.

\section{Метафизическая модель}

Древний человек относился к миру сновидений не менее серьёзно, чем к миру реальному, и даже более: то, что происходило в сновидении, подчас было гораздо важнее того, что происходило наяву. Это отношение вполне естественно, поскольку люди доверяли всему, что они видели во сне. Возможно, именно сновидения породили первые метафизические представления - предположения о том, что за пределами «этого мира» существует некий «иной мир». Стало быть, метафизическая модель представлений о сновидениях - это наиболее ранняя из рассматриваемых нами моделей, которая в целом характеризуется следующим набором представлений.

Источник сновидения. Отличительная особенность метафизической модели состоит в том, что источником сновидения здесь является не реальность - физическая или психическая, - а находящийся за её пределами некий «иной мир»: духовный, трансцендентный, потусторонний, загробный и пр. Источник может в той или иной степени конкретизироваться и даже персонализироваться: божественное существо, высшая сила, ангел, умерший человек, дьявол и пр.

Функция сновидения. В рамках метафизической модели можно различить позитивные и негативные функции сновидения, что связано с характерной для религиозного сознания дихотомией. Позитивная функция сновидения реализуется в виде некоего «истинного послания» или «полезного воздействия»: знамение, благовещение, пророчество, предупреждение, вдохновение ${ }^{1}$; если же говорить о негативной функции сновидений, то она реализуется в виде «ложного послания» или «вредного воздействия»: искушение, обман, вторжение злых сил, одержимость и пр. В религиозном сознании сновидения представляют собой одну из наиболее распространённых форм общения человека с Богом, так, например, в Библии, начиная с книги Бытия и заканчивая Откровением Иоанна

\footnotetext{
1 Анализируя представления традиционных культур, О.Б. Христофорова называет следующие способы воздействия «духов» на сновидящего: просьба, требование, наставление, благоволение (Христофорова, 1998).
}

Богослова, сновидения выступают посредниками между Богом и людьми ${ }^{2}$; предполагается, что большая часть Корана записана со слов пророка Магомета, которые он услышал во сне. Роль сновидений в буддизме вообще трудно переоценить: например, считается, что последователи Будды, достигшие просветления, могут во сне посещать Будд и получать от них наставления и тексты; точно также большинство иконографических канонов было взято из сновидений наиболее авторитетных адептов буддизма ${ }^{3}$. Таким образом, функции сновидений выходят за рамки жизни одного человека (сновидящего) и уже касаются судьбы целой группы людей, объединённых одной конфессией, или даже народа ${ }^{4}$. Описаны случаи, когда сновидения некоторых «референтных лиц» выполняли функцию урегулирования внутрикультурных противоречий и тем самым становились источником социальных и культурных инноваций и трансформаций; яркий пример: шаманы Папуа - Новой Гвинеи убедили людей принять христианство, ссылаясь на свои сны о Боге, Иисусе и Святом духе 5 .

Причина сновидения. Необходимость «вмешательства» сил или персонажей «иного мира»в жизнь человека возникает в силу разных причин. Видимо, чаще всего поводом для их «активации» являются действия человека или какой-либо социальной группы, которые так или иначе становятся значимыми для «иного мира». Например, благочестивые действия (молитва, добродетельные поступки и пр.) могут стать причиной вмешательства как «добрых сил» (божественное вдохновение), так и «злых» (дьявольское искушение); неблагочестивые действия (греховные поступки) также могут вызвать «резонанс» в «ином мире» и стать причи-

\footnotetext{
2 Вот два примера. В Ветхом завете Бог говорит: «...если бывает у вас пророк Господень, то Я открываюсь ему в видении, во сне говорю с ним» (Числа. 12:6). В Новом завете читаем, как Иосифу во сне явился ангел и сказал: «Иосиф, сын Давидов! Не бойся принять Марию, жену твою; ибо родившееся в Ней есть от Духа Святого» (Матф. 1:20).

3 Рабинович Е.И. Сновидение как механизм модернизации традиционной культуры Тибета // Известия Уральского государственного университета. Гуманитарные науки. 2011. T. 87. № 1. C. 17-24.

4 В качестве примера могут выступить описанные в Библии сны Иосифа (Быт. 37:6-9), сны фараона, растолкованные Иосифом (Быт, 41:17-36), сон о мече Гедеона (Суд. 7:1314), сон Мардохея (Есф. 1:1; Есф. 10:3), сны Навуходоносора, растолкованные Даниилом (Дан. 2:28-45; Дан. 4:6-25), сон Даниила (Дан. 7).

5 Рабинович Е.И. Сновидение как механизм модернизации традиционной культуры Тибета // Известия Уральского государственного университета. Гуманитарные науки. 2011. T. 87. № 1. C. 18.
} 


\section{Психология и психотехника 3(90) • 2016}

ной «предупреждающих» сновидений или, напротив, «захвата» спящей души злыми духами. В рамках метафизической модели остаётся открытым вопрос: всегда ли «высшие силы» вмешиваются по причине каких-либо действий человека (человечества), или они могут инициировать сновидение исходя из своих собственных мотивов?

Механизм сновидения. Вмешательство «иных сил» в рамках метафизической модели понимается как преодоление границы между двумя мирами. Так, «агент иного мира» просто «проникает» в сновидческую реальность, во-первых, потому что он достаточно могущественен для этого, во-вторых, сама сновидческая реальность рассматривается как потусторонняя, а сновидение - это «путешествие души» в другой мир, и в этом случае речь идёт не столько о вмешательстве «потустороннего», сколько о встрече с «потусторонним». Таким образом, можно выделить два механизма сновидения в рамках метафизической модели: проникновение извне внутрь и выход изнутри наружу, но в любом случае мы имеем дело с преодолением границы (трансгрессией). Заметим, что в связи с принципиальной поляризацией «иного мира» переход границы может нести как положительную, так и отрицательную функции, отсюда разные слова, описывающие этот процесс: «откровение», «вдохновение» - для положительного проникновения, «одержимость»для отрицательного проникновения; «экстаз», «духовное путешествие» - для положительного выхода, «блуждание» - для отрицательного выхода.

Онейропрактики. Метафизическая модель породила многообразные сновидческие практики. Например, предполагалось, что с помощью специальной подготовки, заклинаний, молитвы можно инициировать пророческое сновидение или откровение, в котором сновидящий получает ответ на поставленный вопрос. В древние времена существовали специальные люди, специальные места и ритуалы для вызывания и последующего толкования пророческих сновидений; в традиционных культурах онейропрактики были естественным образом вплетены в повседневную жизнь ${ }^{6}$. Характерный признак развитых онейропрактик - создание так называемых «сонников» - «справочников» по толкованию сновидений. Все древние культуры имели такие руководства. Одно из самых знаменитых - «Онейрокритика» Артемидора7 , в котором автор проложил границу между обыкновенными сно-

\footnotetext{
6 Примеры см.: Бескова И.А. Природа сновидений (эпистемологический анализ). М.: ИФ РАН, 2005. С. 18-19, 57-62.

Артемидор. Онейрокритика / Пер. с древнегреч. СПб.: Кристалл, 1999.
}

видениями и пророческими; вторые он разделил на «прямые» и «аллегорические». Именно последние нуждаются в специальной процедуре толкования.

Христианская религия разделяла представления о сновидениях как «каналах» для божественного откровения, но при этом не исключалась возможность использования состояния сна «злыми силами». Это повлияло на отношение к существовавшим в античности онейропрактикам. Так, весьма противоречиво христианство относилось к практике истолкования сновидений: с одной стороны, признавалось существование «истинных видений», в которых можно получить подлинные картины будущего, с другой стороны, возможность встретиться с ними была исключительно у великих святых и мучеников. Дело в том, что «сны от дьявола» по своему содержанию могут «имитировать» сны пророческие (что «от Бога»), но предполагается, что лишь святой способен отличить сон «божественный» от «дьявольского» ${ }^{8}$. Поэтому простых людей Церковь старалась отвратить от практики истолкования снов. Так, например, Первый поместный собор, состоявшийся в Анкире в 314 г., принял канон XXIII, который гласил: «Те же, кто сохраняет языческие привычки и соблюдает указания авгуров или ауспиков, гадателей по сновидениям или иных прорицателей, или же приводит в дом к себе людей, дабы просить их предсказать будущее с помощью колдовского искусства <...> они присуждаются к исповеди и пятилетнему покаянию» ${ }^{9}$. И хотя официально практика истолкования сновидений не поощрялась, у людей, тем не менее, такая потребность, безусловно, существовала. «Испытывая недоверие к сновидениям, Церковь попыталась упорядочить практику их истолкования, выделив две категории привилегированных сновидцев, которые имели право и возможность видеть истинные, пророческие сны. Первая - это монархи, вторая - святые праведники» [6, с. 39-40]. Простые же люди шли за разъяснением своих снов к колдунам и знахарям, что, естественно, воспрещалось официальной церковью.

\section{Естественнонаучная модель}

В связи с развитием в конце XIX в. естественных наук появился новый взгляд на сновидения. Естественнонаучная модель опиралась на мате-

В Библии дело доходит до того, что даже сам Бог призывает не верить снам некоторых пророков (Иерем. 23: 25-32).

9 Экзегетика снов: европейские хроники сновидений / Сост., комм. В. Звиняцковского, науч. ред. В. Чугунова. М.: Эксмо, 2002. С. 160. 
риалистическую парадигму, а потому - в отличие от метафизической модели - не признавала какого-либо «иного мира». Наука полностью избавила сновидение от мистического ореола. Все представления о сновидениях в «чистой» естественнонаучной модели укладываются в рамки воззрений таких наук, как нейрофизиология и психофизиология. Здесь уже нет того богатства онейропоэтики и захватывающих сюжетов, свойственных метафизической модели.

Любопытно, что зерна естественнонаучной модели зародились ещё в недрах метафизических представлений. Так, Гераклит объяснял сон закрытием органов чувств, в результате чего внешний мир не может проникнуть внутрь тела спящего, а поэтому во время сна человек создаёт свой собственный мир. Демокрит связывал сновидения с остаточным волнением органов чувств, которое продолжается ещё и тогда, когда прекращается непосредственное воздействие внешних предметов на них ${ }^{10}$. Позднее Аристотелем были написаны трактаты на тему сновидений ${ }^{11}$, в которых он отрицал божественное происхождение сновидений, включая их в круг явлений природы. Вслед за Демокритом он полагал, что образы сновидений - ни что иное, как продукт деятельности наших органов чувств, совершающейся после того, как чувственное восприятие, связанное с непосредственным воздействием внешних предметов, прекратилось ${ }^{12}$.

Позднее, в XVIII-XIX вв., такие философы и учёные, как Т. Гоббс, Ж.О. де Ламетри, П. Кабанис, Я. Пуркинье и др., высказывались в духе физиологии XX в., рассматривая сновидение как состояние, промежуточное между бодрствованием и глубоким сном, во время которого прерывается деятельность многих внешних чувств, и часть функций мозга прекращает своё действие. К концу XIX в. наука полностью обесценила феномен сновидения и даже поставила его в один ряд с некоторыми патологическими феноменами - иллюзиями, галлюцинациями, бредом и даже психозами; примером могут служить взгляды В.Кандинского, А. Мори, Э. Крепелина и др. Лишь позднее, в рамках естественнонаучной парадигмы, появились интерпре-

\footnotetext{
10 Артемидор. Онейрокритика / Пер. с древнегреч. СПб.: Кристалл, 1999. С. 33.

11 Аристотель. О сновидениях / Пер. О.А. Чулкова // Академия. Вып. 6. СПб., 2005. С. 423-432; Аристотель. О предсказаниях во сне / Пер. М.А. Солоповой // Интеллектуальные традиции античности и средних веков (Исследования и переводы). М.: Кругъ, 2010. С. 169-175.

12 Артемидор. Онейрокритика / Пер. с древнегреч. СПб.: Кристалл, 1999. С. 34.
}

тации, в которых сновидение выполняло некоторые положительные для организма функции ${ }^{13}$.

Качественно новый этап в изучении сна наступил в 1937 г., когда использование Е. Харвеем, А. Лумисом и Е. Хабартом электроэнцефалографии (ЭЭГ) позволило объективно выделить отдельные фазы сна. Дальнейшим прорывом стало обнаружение Н.Клейтманом и Ю.Азерински тесной связи между периодом быстрых движений глаз (БДГсон) и сновидениями ${ }^{14}$. Только после этого стали задумываться о значении фазы сновидений в жизни человека. Позднее был выявлен своеобразный «эффект отдачи», который состоит в том, что если испытуемых подвергнуть БДГ-депривации, т.е. будить сразу при возникновении согласованных движений глаз (и тем самым лишать сновидений), то в первую же ночь, когда испытуемых предоставляют самим себе, время, проведённое в БДГ-фазе, значительно увеличивается: человек, которого в предыдущую ночь лишили сновидений, будет навёрстывать упущенное следующей ночью. Ничего подобного не было отмечено у тех же испытуемых, если их будили столь же часто, но в других фазах сна, вне БДГ-активности. «Редко, кто выдерживал более семидесяти двух часов без сновидений. А у тех, кто выдерживал, в итоге начинались галлюцинации. Создаётся впечатление, что таким образом мозг пытается создать замену сновидениям, которых его лишили» ${ }^{15}$. Сегодня, после многочисленных экспериментов, едва ли кто сомневается в жизненной необходимости сновидений, хотя представления об их конкретных функциях до сих пор носят гипотетический характер.

Итак, рассмотрим характерные особенности представлений о сновидениях в рамках естественнонаучной модели.

Источник сновидения. По сути, единственными источниками сновидческих образов и переживаний в рамках естественнонаучной модели являются память человека, его воображение и его текущее восприятие.

Функция сновидения. На заре проникновения естественнонаучного мышления в область понимания человеческой души сновидение рассматривалось как иррациональная, спонтанная, хаотичная и бессмысленная работа спящего мозга, у которой нет какой-либо значимой для организма функции,

\footnotetext{
13 Бескова И.А. Природа сновидений (эпистемологический анализ). М.: ИФ РАН, 2005. С. 43-47.

14 Корен С. Тайны сна: путешествие в загадочный мир сна. М.: Вече, АСТ, 1997. С. 50-52.

15 Линн Д. Полные пригоршни снов. Раскройте тайну мира сновидений. Киев: София, 2000.
} 


\section{Психология и психотехника 3(90) • 2016}

а потому сновидение не рассматривалось как достойный объект научных исследований. Позднее сновидению начали приписывать некоторые физиологические и когнитивные функции, например, функция своеобразного отражения-преображения - «небывалая комбинация бывалых впечатлений», по И.П. Павлову; образное переживание физиологических и патологических процессов, происходящих в момент сна в телесной сфере ${ }^{16}$; сновидение - это источник эмоций и переживаний, заполняющих ночной вакуум, это компенсация естественной сенсорной и эмоциональной депривации, связанной с отключением во время сна сенсорных систем от восприятия внешних воздействий ${ }^{17}$; или более сложные функции, например, существуют предположения, что фаза сновидений - необходимое условие для развития головного мозга, что сновидения способствуют более эффективному обучению и закреплению информации в долговременной памяти, что во время БДГ-сна восстанавливаются оперативные функции интеллекта после дневных нагрузок и т.д. ${ }^{18}$.

Причина сновидения. Факторами, инициирующими сновидения, могут быть «внешние», например: яркие события дня, стимулы, воздействующие на человека во время сна и пр., и «внутренние»: телесные ощущения, возникающие в теле сновидца, спонтанные воспоминания, образы, ассоциации и пр.

Механизм сновидения. Естественнонаучное представление о природе сновидения можно выразить в краткой формуле: сновидение - это продукт деятельности мозга. Во время сна активность телесной мускулатуры блокируется стволовыми отделами мозга, в то время как кора больших полушарий находится в состоянии избирательного возбуждения и торможения, что создаёт в сознании спящего иллюзию собственных движений, «внешних» событий, взаимодействия с какими-то персонажами и пр. При этом возникает вопрос: насколько упорядочена активность мозга во время сновидения? Например, ещё И.П. Павлов говорил о хаотическом растормаживании участков коры, определяющем спонтанный и непредсказуемый характер сновидения ${ }^{19}$, и, похоже, большинство последователей естественнонаучной модели придерживаются этой позиции до сих пор. При описании механизма порождения

\footnotetext{
16 Касаткин В.Н. Теория сновидений. Л.: Медицина, 1983.

17 Авакумов С.В. Психология сновидений // Учёные записки университета им. П.Ф. Лесгафта. 2008. № 5. С. 3-7.

18 Бескова И.А. Природа сновидений (эпистемологический анализ). М.: ИФ РАН, 2005. С. 71-92.

19 Павлов И.П. Проблемы сна. Киев: Госмедиздат, 1953. 347 с.
}

сновидений чаще всего используются привычные для нейрофизиологии и психофизиологии термины: «возбуждение», «торможение», «расслабление», «напряжение», «раздражители», «ритмы мозговой активности», «фаза быстрого сна», «парадоксальная фаза», «БДГ-фаза» и пр.

Онейропрактики. Сновидческие практики в естественнонаучной модели можно разделить на экспериментальные (лабораторные) и утилитарные. Цель экспериментальных практик - с помощью различной исследовательской техники (ЭЭГ, МРТ и пр.) лучше понять механизмы и физиологическое значение феноменов сна и сноподобных состояний; примером могут служить эксперименты по депривации сна (БДГ-депривации), сенсорной депривации, моделированию изменённых состояний сознания. При этом надо заметить, что естественнонаучный подход к сновидению чаще всего ограничивается изучением сна, а не сновидений. Утилитарные практики в основном сведены к различным мероприятиям по улучшению «качества сна» (аутогенная тренировка, использование лекарственных препаратов и пр.).

\section{Психологическая модель}

Если естественнонаучная модель - это антитеза метафизической модели, то психологическая модель возникла как оппозиция к первой и второй. В основу психологической модели легла теория сновидений 3. Фрейда ${ }^{20}$, которая впоследствии дополнялась и видоизменялась другими представителями психодинамической парадигмы (А. Адлер, К. Юнг и др. $)^{21}$.

Источник сновидения. В рамках психодинамической парадигмы основным источником материала для сновидений являются нереализованные желания, «вытесненные инстинктивные импульсы», «бессознательные структуры», «коллективное бессознательное» и пр.

Функция сновидения. С точки зрения Фрейда, главная функция сновидения - обеспечение психологического комфорта путём осуществления в сновидной (символической) форме неосуществлённых в период бодрствования желаний; сновидение - это относительно безобидный способ реализации бес-

\footnotetext{
20 Имеется в виду работа Фрейда, вышедшая в свет в 1900 г. под названием «Толкование сновидений». Кроме того, Фрейд не раз возвращался к теме сновидений. Наиболее полный и законченный вид теория сновидений имеет в знаменитых «Лекциях», прочитанных Фрейдом в 1915-1917 гг.

21 Трунов Д.Г. Развитие психодинамической теории сновидений // Московский психотерапевтический журнал. 2009. № 1. С. 64-74.
} 
сознательных инстинктивных импульсов, а также разрешения внутриличностных конфликтов, их эмоционального отреагирования. С точки зрения Юнга, сновидение - это послание бессознательного, цель которого - встреча человека с теневой часть его души и возвращение её к целостности («самости»), преодоление поляризации души и попытка её интеграции. Адлер считал, что сновидение - это репетиция исполнения желания или достижения целей жизни; сновидение представляет собой стремление предсказать будущее, в нём человек прогнозирует трудности, которые могут встретиться на пути реализации этого будущего.

Причина сновидения. Пусковые факторы сновидения различаются в зависимости от психологической концепции: вытесненный внутриличностный конфликт, возникший как реакция на психотравмирующую ситуацию, чаще в далёком детстве (Фрейд), неприятие человеком теневой стороны своей души (Юнг), желания и жизненные цели индивида (Адлер).

Механизм сновидения. С точки зрения Фрейда, во время сна критическая функция «цензуры» (нравственных запретов) ослабевает настолько, что вытесненные импульсы начинают проникать в сознание индивида. И хотя в сновидении неосознаваемые желания и тенденции проявляются более открыто, чем в бодрствующем состоянии, тем не менее «цензура» во сне полностью не исчезает - она не позволяет наиболее неприемлемым для личности желаниям проявиться прямо. Психика проделывает своеобразную «работу сновидения», которая состоит в трансформации материала, поступающего из бессознательного, в более или менее подходящую для сновидца форму ${ }^{22}$. Таким образом, Фрейд в сновидениях выделяет два уровня содержания сновидения: явное содержание и скрытое содержание: явное содержание составляют образы, персонажи, события, которые человек видит в сновидении и запоминает при пробуждении; скрытое содержание составляют вытесненные ранее (главным образом в детстве) социально неприемлемые инстинктивные импульсы (сексуальные, агрессивные чувства и желания).

Главное отличие позиции Юнга от подхода Фрейда заключается в том, что сновидение не скрывает «прорывающееся» бессознательное, а само по себе уже является проявлением бессознательного как такового. Юнг не видел разницы

\footnotetext{
22 Как известно, Фрейд описывал разные виды таких трансформаций-искажений первоначального материала сновидений: сгущение, опущение, символизация, вторичная обработка и пр.
}

между явным и скрытым содержанием сновидения: по его мнению, материал бессознательного презентирует себя в сновидении самым непосредственным образом; сновидение - это «окно в бессознательное». Язык сновидения - это настоящий язык бессознательного, а сновидение - это послание человека к самому себе и о самом себе. По Юнгу, всё, что человек видит во сне, - это он сам, его душа в своих разнообразных проявлениях. Каждый объект, персонаж, предмет - это «проекция» одной из многочисленных «частей личности» человека: его желание, мотив, черта характера, социальная роль, чувство, представление о себе в будущем и пр. Сновидение представляет собой специфическую форму внутреннего диалога между различными структурами - сознательными и бессознательными; движущей же силой этого диалога, обуславливающего содержание сновидения, является стремление к целостности, проявляющееся, в частности, в попытках синтеза с вытесненными структурами и переживаниями ${ }^{23}$.

В отличие от Фрейда Адлер считал, что сновидение - это переживание будущих событий, а не событий, которые когда-то были вытеснены в бессознательное. Согласно Адлеру, жизнь человека и его поведение определяются его целями и желаниями, и сновидение не является исключением, в нём человек «проигрывает» свои планы, свои надежды, свои страхи. Адлер считал сновидения бессознательным способом сосредоточения на наиболее значимых жизненных целях. В сновидении желания и цели выходят на передний план, заостряются, акцентируются, преувеличиваются, а потому, нередко, сновидения показывают не просто исполнение желаний, а рисуют грандиозные картины исполнения любых, даже самых невообразимых фантазий.

Онейропрактики. Фрейд вернул сновидениям статус феномена, достойного внимания как исследователя, так и самого человека-сновидца. В частности, он реабилитировал практику толкования сновидений, хотя исходил он, конечно, при этом из своей концепции. Для Фрейда сновидение - это «царская дорога» в бессознательное, но для того, чтобы пройти по этой дороге, нужно совершить работу, обратную «работе сновидения», - с помощью техник свободных ассоциаций и интерпретации расшифровать символику сновидения, т.е. перейти от явного уровня сновидения к скрытому. Отсюда появление в рамках психодинамической парадигмы нового типа «сонников», где, несмотря на при-

23 Холл Дж. Юнгианское толкование сновидений. Практическое руководство. СПб.: Б.С.К., 1996. С. 44-48. 


\section{Психология и психотехника 3(90) • 2016}

зывы к индивидуальному подходу в толковании сновидений, сосредоточились наиболее типичные интерпретации сновидческих «символов» ${ }^{24}$.

В противовес классическому психоанализу Адлер считал, что сновидение необходимо рассматривать, во-первых, в контексте будущего, а во-вторых - в контексте социальных взаимоотношений; по мнению Адлера, в сновидении можно увидеть как неосознаваемый жизненный план, так и стиль жизни, с помощью которого человек стремится справиться со своими главными задачами: адаптацией к жизни и своей неуверенностью ${ }^{25}$.

В определённом смысле Юнг интегрировал интерпретативные стратегии Фрейда и Адлера, ориентированные соответственно на прошлое и на будущее: он различал ретроспективный анализ сновидения, под которым понимал перенесение содержания сновидения в контекст ситуаций и обстоятельств прошлого (в том числе ближайшего прошлого), и проспективный анализ - рассмотрение содержания сновидения в контексте будущего личности ${ }^{26}$. Кроме того, Юнг, пожалуй, более всех остальных начал активно вмешиваться в содержание сновидения и разработал большое количество разнообразных техник работы со сновидением, позволяющих расширить его содержание ${ }^{27}$. Например, он предлагал клиенту нарисовать сновидение, пластически выразить его, разыграть сюжет сновидения, вступить в диалог с одним из персонажей сновидения и поговорить от его имени, придумать продолжение сновидения и т.д. ${ }^{28}$.

\section{Возможна ли интеграция моделей?}

Как уже говорилось выше, к настоящему моменту накопилось огромное количество разнообразных «теорий сновидений», каждая из которых претендует (в кругах своих последователей) на право «истинной». Это разнообразие, по словам

\footnotetext{
24 Примером «стандартизирования» символики сновидений может служить «сонник» Антонио Менегетти. Противоположный - альтернативный символическому - метафорический подход к сновидениям, опирающийся только на индивидуальное толкование, описан в [18].

25 Адлер А. Сны и их толкование // Адлер А. Практика и теория индивидуальной психологии. М.: Фонд «За экономическую грамотность», 1995. С. 237-254.

26 Юнг К. Тэвистокские лекции. СПб.: Кентавр, 1995.

27 Холл Дж. Юнгианское толкование сновидений. Практическое руководство. СПб.: Б.С.К., 1996.

28 Некоторые перспективы развития онейропрактик в рамках психологической модели намечены здесь: Трунов Д.Г. Онейротерапия - путь сновидений // Психологическая газета. 2004. № 11. С. 16-17.
}

И.А. Бесковой, создаёт «методологический кризис», поскольку один и тот же феномен сновидения интерпретируется «не только по-разному, но зачастую противоположным образом» ${ }^{29}$. Выходом из этого И.А. Бескова считает создание интегрального («объёмного») подхода к пониманию природы сновидений. Однако, на наш взгляд, эта задача является невыполнимой в силу принципиальных разногласий между различными «теориями сновидений». Попытка создать какую-либо «интегративную модель» сновидений приводит лишь к появлению новой «теории сновидения» и нисколько не «снимает с повестки дня» и не обесценивает предыдущие концепции.

Дело в том, что определяющим критерием, позиционирующим любую теорию сновидения относительно других, является представление об источнике сновидения: если источник располагается вне реального (физического) мира, то это означает, что концепция тяготеет к метафизической модели, если источник принадлежит физическому миру, то скорее всего мы имеем дело с естественнонаучной концепцией, если же источник помещается в особом, психическом пространстве (которое по своей феноменальной сущности не является ни физическим, ни метафизическим), то перед нами психологическая концепция сновидений.

Отсюда понятно, что метафизическая и естественнонаучная модели принципиально противопоставлены друг другу и едва ли могут быть интегрированы между собой, а вот психологическая модель занимает в определённом смысле двойственное положение: с одной стороны, она не нуждается в концепте «иного мира» для объяснения феномена сновидения - это сближает её с естественнонаучной моделью, а с другой стороны, она утверждает некую гипотетическую идеальную (ирреальную) сферу, каковым является, например, «бессознательное», которое нельзя непосредственно ни почувствовать, ни зарегистрировать никакими приборами. Ну чем не метафизика?! Надо заметить при этом, что фрейдовское «Оно» с его биологическими инстинктами больше тяготеет к естественнонаучной модели, а юнговское «коллективное бессознательное» практически представляет из себя метафизический конструкт. Поэтому концептуальное взаимодействие психологической модели с двумя другими вполне возможно ${ }^{30}$. Ре-

\footnotetext{
29 Бескова И.А. Природа сновидений (эпистемологический анализ). М.: ИФ РАН, 2005. С. 5.

30 Только нужно понимать, что речь не идет об интеграции двух моделей, при которой происходит полноценное объединение, но лишь о частичном взаимодействии.
} 
зультатом этого взаимодействия становится рождение новой «теории сновидений», представляющей своеобразный более или менее согласованный компромисс, что-то вроде мозаики, сложенной из терминов и концептов, заимствованных из «родительских» теорий.

В настоящее время таких «компромиссных концепций» сновидений очень много. Например, попытки интегрировать психологическую и естественнонаучную модели были предприняты B.C. Ротенбергом ${ }^{31}$, С.В. Авакумовым, в чьих работах активно используются дискурсы отечественной психологии, психиатрии, нейрофизиологии и психоанализа. Одним из примеров компромиссной концепции, занимающей промежуточное положение между психологической и метафизической моделью, можно считать концепцию С. Грофа, в ко- торой первоначальная психологическая ориентация на изучение перинатального опыта, т.е. бессознательных переживаний, связанных с периодом беременности и родов, «обогатилась» метафизическими представлениями о возможности переживания в сновидениях или других изменённых состояниях сознания трансперсонального опыта, т.е. выхода за пределы физической реальности ${ }^{32}$. Весьма любопытным примером в плане интеграции различных концепций может также служить концепция А. Минделла, которая стремится занять промежуточное положение между психологической, естественнонаучной и даже метафизической моделью ${ }^{33}$ : в ней феномен сновидения описывается не только в научных - психологических и физических - терминах, но и в выражениях, заимствованных из традиционных верований ${ }^{34}$.

\section{Список литературы:}

1. Авакумов С.В. Психология сновидений // Учёные записки университета им. П.Ф. Лесгафта. 2008. № 5. С. 3-7.

2. Адлер А. Сны и их толкование // Адлер А. Практика и теория индивидуальной психологии. М.: Фонд «За экономическую грамотность», 1995. С. 237-254.

3. Аристотель. 0 сновидениях / Пер. О.А. Чулкова // Академия. Вып. 6. СПб., 2005. С. 423-432.

4. Аристотель. 0 предсказаниях во сне / Пер. М.А. Солоповой // Интеллектуальные традиции античности и средних веков (Исследования и переводы). М.: Кругъ, 2010. С. 169-175.

5. Артемидор. Онейрокритика / Пер. с древнегреч. СПб.: Кристалл, 1999.

6. Бескова И.А. Природа сновидений (эпистемологический анализ). М.: ИФ РАН, 2005.

7. Гроф С. За пределами мозга: рождение, смерть и трансценденция в психотерапии. М.: Изд-во Трансперсональный институт, 1993.

8. Касаткин В.Н. Теория сновидений. Л.: Медицина, 1983.

9. Корен С. Тайны сна: путешествие в загадочный мир сна. М.: Вече, АСТ, 1997.

10. Линн Д. Полные пригоршни снов. Раскройте тайну мира сновидений. Киев: София, 2000

11. Менегетти А. Словарь образов: практическое руководство по имагогике. Л.: ЭКОС, 1991.

12. Минделл А. Ученик создателя сновидений. Использование более высоких состояний сознания для интерпретации сновидений. М.: Урания, 2003.

13. Павлов И.П. Проблемы сна. Киев: Госмедиздат, 1953. 347 с.

14. Рабинович Е.И. Сновидение как механизм модернизации традиционной культуры Тибета // Известия Уральского государственного университета. Гуманитарные науки. 2011. Т. 87. № 1. С. 17-24.

15. Ротенберг В.С. Сновидения, гипноз и деятельность мозга. М.: Центр гуманитарной литературы РОН, 2001.

16. Трунов Д.Г. Онейротерапия путь сновидений // Психологическая газета. 2004. № 11. С. 16-17.

17. Трунов Д.Г. Развитие психодинамической теории сновидений // Московский психотерапевтический журнал. 2009. № 1. С. 64-74.

18. Трунов Д.Г. Терапевтическое толкование сновидения: от символа к метафоре // Психология и психотехника. 2010. № 8. С. 105-110.

19. Фрейд 3. Толкование сновидений. Обнинск: Титул, 1992.

31 Ротенберг В.С. Сновидения, гипноз и деятельность мозга. М.: Центр гуманитарной литературы РОН, 2001.
32 См., например: Гроф С. За пределами мозга: рождение, смерть и трансценденция в психотерапии. М.: Изд-во Трансперсональный институт, 1993.

33 Дело в том, что Арнольд Минделл по первому образованию был физиком, затем увлекся юнгианским психоанализом, а кроме того, активно интересовался традиционными культурами. О его «интегративной» направленности красноречиво свидетельствует название одной из его книг: «Квантовый ум: грань между физикой и психологией» (Quantum mind: the edge between physics and psychology).

34 Описание концепции Минделла можно найти в исследовательской литературе [6, с. 93-100] или в его книгах, например, «Ученик создателя сновидений». 


\section{Психология и психотехника 3(90) • 2016}

20. Фрейд З. Введение в психоанализ: лекции. М.: Наука, 1989. Часть вторая: Сновидения. С. 50-153.

21. Холл Дж. Юнгианское толкование сновидений. Практическое руководство. СПб.: Б.С.К., 1996.

22. Христофорова О.Б. К вопросу о структуре приметы // Arbor mundi. 1998. № 6. С. 30-47.

23. Штаерман Е.М. «Сонник» Артемидора как исторический источник // Вестник древней истории. 1989. № 3. С. 236251.

24. Экзегетика снов: европейские хроники сновидений / Сост., комм. В. Звиняцковского, науч. ред. В. Чугунова. М.: Эксмо, 2002.

25. Юнг К. Тэвистокские лекции. СПб.: Кентавр, 1995.

\section{References (transliterated):}

1. Avakumov S.V. Psikhologiya snovidenii // Uchenye zapiski universiteta im. P.F. Lesgafta. 2008. № 5. S. 3-7.

2. Adler A. Sny i ikh tolkovanie // Adler A. Praktika i teoriya individual'noi psikhologii. M.: Fond «Za ekonomicheskuyu gramotnost'», 1995. S. 237-254.

3. Aristotel'. 0 snovideniyakh / Per. O.A. Chulkova // Akademiya. Vyp. 6. SPb., 2005. S. 423-432.

4. Aristotel'. O predskazaniyakh vo sne / Per. M.A. Solopovoi // Intellektual'nye traditsii antichnosti i srednikh vekov (Issledovaniya i perevody). M.: Krug", 2010. S. 169-175.

5. Artemidor. Oneirokritika / Per. s drevnegrech. SPb.: Kristall, 1999.

6. Beskova I.A. Priroda snovidenii (epistemologicheskii analiz). M.: IF RAN, 2005.

7. Grof S. Za predelami mozga: rozhdenie, smert' i transtsendentsiya v psikhoterapii. M.: Izd-vo Transpersonal'nyi institut, 1993.

8. Kasatkin V.N. Teoriya snovidenii. L.: Meditsina, 1983.

9. $\quad$ Koren S. Tainy sna: puteshestvie v zagadochnyi mir sna. M.: Veche, AST, 1997.

10. Linn D. Polnye prigorshni snov. Raskroite tainu mira snovidenii. Kiev: Sofiya, 2000.

11. Menegetti A. Slovar' obrazov: prakticheskoe rukovodstvo po imagogike. L.: EKOS, 1991.

12. Mindell A. Uchenik sozdatelya snovidenii. Ispol'zovanie bolee vysokikh so-stoyanii soznaniya dlya interpretatsii snovidenii. M.: Uraniya, 2003.

13. Pavlov I.P. Problemy sna. Kiev: Gosmedizdat, 1953. 347 s.

14. Rabinovich E.I. Snovidenie kak mekhanizm modernizatsii traditsionnoi kul'tury Tibeta // Izvestiya Ural'skogo gosudarstvennogo universiteta. Gumanitarnye nauki. 2011. T. 87. № 1. S. 17-24.

15. Rotenberg V.S. Snovideniya, gipnoz i deyatel'nost' mozga. M.: Tsentr gumanitarnoi literatury RON, 2001.

16. Trunov D.G. Oneiroterapiya put' snovidenii // Psikhologicheskaya gazeta. 2004. № 11. S. 16-17.

17. Trunov D.G. Razvitie psikhodinamicheskoi teorii snovidenii // Moskovskii psikhoterapevticheskii zhurnal. 2009. № 1. C. 64-74.

18. Trunov D.G. Terapevticheskoe tolkovanie snovideniya: ot simvola k metafore // Psikhologiya i psikhotekhnika. 2010 . № 8. S. 105-110.

19. Freid Z. Tolkovanie snovidenii. Obninsk: Titul, 1992.

20. Freid Z. Vvedenie v psikhoanaliz: lektsii. M.: Nauka, 1989. Chast' vtoraya: Snovideniya. S. 50-153.

21. Kholl Dzh. Yungianskoe tolkovanie snovidenii. Prakticheskoe rukovodstvo. SPb.: B.S.K., 1996.

22. Khristoforova O.B. K voprosu o strukture primety // Arbor mundi. 1998. № 6. C. 30-47.

23. Shtaerman E.M. «Sonnik» Artemidora kak istoricheskii istochnik // Vestnik drevnei istorii. 1989. № 3. S. 236-251.

24. Ekzegetika snov: evropeiskie khroniki snovidenii / Sost., komm. V. Zvinyatskovskogo, nauch. red. V. Chugunova. M.: Eksmo, 2002.

25. Yung K. Tevistokskie lektsii. SPb.: Kentavr, 1995. 